Agro-Science Journal of Tropical Agriculture, Food, Environment and Extension Volume 14 Number 2 May 2015 pp. $18-23$

ISSN $1119-7455$

\title{
DETERMINANT OF SOIL MANAGEMENT PRACTICES IN CEREAL BASED PRODUCTION SYSTEMS AMONG SMALL-SCALE FARMERS IN KWARA STATE
}

\author{
${ }^{1}$ Oloyede, A.O; ${ }^{1}$ Muhammad-Lawal, A; ${ }^{1}$ Ayinde, O.E; and ${ }^{2}$ Omotesho, K. F \\ ${ }^{1}$ Department of Agricultural Economics and Farm Management, University of Ilorin, PMB \\ 1515, Ilorin, Kwara State, Nigeria. \\ ${ }^{2}$ Department of Agricultural Extension and Rural Development, University of Ilorin, PMB \\ 1515, Ilorin, Kwara State, Nigeria. \\ oloyedeadeola@yahoo.com or opeayinde@yahoo.com
}

\begin{abstract}
Soil management practices are known for their efficiency in combating land degradation issues and improving soil productivity, but generally there are low usage levels of these practices by the farmers. The study analyses the influence of socioeconomic factors on the attitude of farmers towards soil management practices in Kwara State. The specific objectives were to determine the soil management practices carried out by cereal farmers in the area and to examine the socio-economic factors affecting the use of soil management practices in cereal based production in the study area. A random sampling technique was used to collect data from 118 cereal farmers in the study area. Descriptive statistics and regression model were the analytical tools used. The study shows that ridging $(94.1 \%)$, crop rotation (74.6\%) and use of fertilizer (69.5\%) were the most common soil management practices among the farmers. Logistic regression model highlighted factors like Age, farm size, number of contacts with extension agents, total labour used and total number of plots cultivated with cereals to influence the use of soil management practices by the farmers. The study recommends that farmers should be encouraged to make use of soil management practices which will bring about soil improvement and also improve their productivity.
\end{abstract}

Keywords: Soil management practice, cereal production, Small scale farmers, Kwara State and Logistic Regression model

\section{INTRODUCTION}

Soil management concerns all operations, practices and treatments used to protect soil and enhance its performance (Wikipedia). They are practices that affect soil quality which includes controlling traffic on soil surface, the use of cover crop and crop rotation, nutrient management and conservation tillage. The goal of soil management is to protect soil and enhance its performance, to farm profitably and preserve environmental quality for decades to come. This implies, the management of agricultural soils would maintain the soils productivity in an ecologically, economically and culturally sustainable system of soil management. Bationo et. al. (2004) further regarded the strategy that helps low resource farmers mitigate many problems and the characteristics of poverty and food insecurity by improving the quantity and quality of food, income and resilience of soil productive capacity as Integrated Soil Fertility Management (ISFM). This is said to involve the utilization of available organic and inorganic sources of plant nutrients in an efficient manner to improve on nutrient use efficiency by the growing crops. According to Rahji and Omotesho (2006), the main issue in the Nigerian agriculture is that of low productivity. The greatest threat to sustaining agricultural productivity in the Nigerian farming communities is the declining productivity of soil caused by the loss of soil fertility through the erosion of top-soil brought about by inappropriate land use practices and the loss of soil water content, soil structure and porosity 
due to persistent laterisation of the top soil as a result of continuous exposure to sun by man and animals (Aromolaran,1998). This transformation of natural resource not only brings the affected land under nature's degradation regime but also accelerates the process. Inherent poor fertility of the soil and low use of organic and inorganic fertilizers have been identified as some of the greatest constraints to increasing agricultural productivity in Nigeria. Also with the population growth, demand for land has increased resulting in intense cultivation with little or no fallow periods and the reliance on continuous cropping rather than conservation cropping systems (Ismaila et.al., 2010; Muhamman and Gungula, 2006; Mrabet, 2011). Inappropriate farming methods on marginal land, deforestation and overgrazing and continual cropping beyond soil threshold limits results into high depletion of the soil (Aruleba and Ajayi, 2011; Cassman, 1999; Tekwa et. al., 2010). The degree of land degradation is very high and is on the increase (Aruleba, 2004). The principal factor limiting optimum crop yields especially in cereal-based farming systems is low fertility amidst land degradation (Tekwa et. al.,2010) even with the use of improved seeds. It is observed that degraded fields occur from cereal-dominated systems with a higher proportion of sorghum and a very low frequency of non-cereal cropping. While intensive agriculture, involving exhaustive high yielding varieties of cereals has led to heavy withdrawal of nutrients from the soil, combined with imbalanced use of chemical fertilizers has resulted in deterioration of soil health (Porpavai et. al., 2011). Cereals after cereals cropping system have been identified as less beneficial to the soil with inadequate input (fertilizer). Nutrient mining of nitrogen $(\mathrm{N})$ has taken place in all areas where cereals are produced. Studies has shown that for each tonne of grains produced for the most commonly grown cereal of maize, rice and sorghum, approximately $60 \mathrm{~kg}$ of nitrogen in plant available form is required but this is not obtainable without proper management of the soil (Oluwatosin et.al., 2004). Hence under this environmental condition, Good soil management practices are essential to maintain sustainable production to meet the current high demand for cereal crops in Nigeria. To increase the yield stability in cereal crops is important in Nigeria of which more than $70 \%$ of the population that live in Savannah region of Nigeria depend largely on small subsistence farming with the productivity of their farming systems being very much limited by soil condition (Kano Soil Health project, 2010; Mrabet, 2011). It is claimed that productivity of the farming systems could only be maintained or sustained through the efficient recycling of organic material such as manure or crop residues in combination with mineral fertilizers and by adopting rotations with grain legumes (Tarawali, 1998). Several indigenous local technologies in use with organic fertilizers have recorded huge successes especially among peasant farmers (Tekwa and Belel, 2008). In spite of all these, recent evidences have shown that farmers have not been eager to adopt or invest in soil management practices. Junge et.al. (2007) observed that some of the farming system practices aimed at tackling soil quality decline and degradation has wide spread acknowledgement with low usage. He further revealed that most of the projects on soil management were carried out on research farms and only a few on-farms with the participation of farmers Therefore there is a need to identify adopted soil management practices and assess them in order to address long term sustainability of Nigeria's soil resources which should be put in place by stakeholders and required to sustain yield increases in the major cereal production systems in Nigeria and to increase the efficiency of farmers in the adoption of researched technologies. With the foregoing, this study analyses the determinants of soil management practices in cereal based production systems among small-scale farmers in Kwara State. Its specific objectives are to determine the soil management practices carried out by cereal farmers in the area and to examine the socio economic factors affecting the use of soil management practices in cereal based production in the study area.

\section{MATERIALS AND METHODS \\ Area of Study}

This study was conducted in Kwara state, Nigeria. The state comprises of 16 local government areas with a population of about 2.37 million (census, 2006). It lies between latitudes $7^{\circ} 45^{\prime} \mathrm{N}$ and $9^{\circ} 30^{\prime} \mathrm{N}$ and longitudes $2^{\circ} 30^{\prime} \mathrm{E}$ and $6^{\circ} 25^{\prime} \mathrm{E}$. (Kwara State Ministry of Information, 2002). Kwara state is made up of four main ethnic groups namely, Yoruba, Nupe, Fulani and Baruba. The daily temperature ranges between $21^{\circ} \mathrm{C}$ to $33^{\circ} \mathrm{C}$. A humid tropical climate prevails over the state and it has two distinct seasons (the wet and dry seasons) which falls between April - July and August - October, while the dry season falls between November and March. Agriculture is the major economic activity of the people. The state has an estimated figure of 260,528 farm families with majority of the farm families living in the rural areas (KWADP, 2006). Primary and secondary data were used for the study. A four 
stage random sampling procedure was employed in selecting the sample for the study. The first stage of data collection comprised a random selection of two zones out of the four zones in Kwara state, of which zone $\mathrm{B}$ and $\mathrm{C}$ were randomly selected and used. The second stage involved a random selection of two Local Government Areas from each zone in which cereal-based farming is majorly done. The Local Government Areas randomly selected and used includes Asa, Edu, Patigi and Ilorin East. The third stage involved a random selection of six villages from each Local Government Area. The fourth stage involved a random selection of five cereal farmers from each of the selected villages. Out of the 120 respondents selected for this study only 118 respondents gave complete data that was used for this survey.

\section{Analytical Techniques \\ Descriptive analysis of data was employed for this study. This involved mean, percentage and frequency distribution to describe socio-economic characteristics and soil management practices of respondents in the study area. To examine the causal relationship between the use of soil management practices and some socio-economic variables binary logistic model was adopted and used.}

The Logistic regression model gives the effect of the various factors on the adoption as well as the predicted probabilities of adoption (likelihood of adoption). The dependent variable in the empirical model is whether or not the farmer use soil management practices or not and the logistic regression characterizing Soil management practices adoption by the sample farmers is specified as follows:

$\mathrm{E}(\mathrm{Yi})=\mathrm{P}(\mathrm{Yi})=\mathrm{e} \alpha+\beta \mathrm{Xi} / 1+$

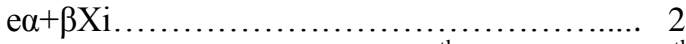
$\mathrm{Pi}$ is the probability of the $\mathrm{i}^{\text {th }}$ farmer with $\mathrm{i}^{\text {th }}$ attributes likely to use the technologies

$\mathrm{E}(\mathrm{Yi})+\mathrm{P}(\mathrm{Yi})=1$, where $\mathrm{Yi}=1$ if the individual farmer use the technologies and $\mathrm{Yi}=0$ if the individual farmer does not use the technology.; $\mathrm{Xi}$ represents a vector of characteristics or attributes associated with the $i^{\text {th }}$ individual. $\beta \mathrm{i}$ is the vector of the estimated coefficients. The regression model is linearlized as follows;

In $(\mathrm{pi} /(1-\mathrm{pi})=\beta \mathrm{o}+\beta 1 \mathrm{X} 1+\beta 2 \mathrm{X} 2 \ldots \beta 8 \mathrm{X} 8+\varepsilon 3$

The dependent variable is the natural log of the probability of adopting (P) divided by the probability of not adopting it (1-P). $\beta$ o is the intercept term, and $\beta 1, \beta 2 \ldots \ldots \beta 8$ are the coefficients associated with each explanatory variable, $\mathrm{X} 1, \mathrm{X} 2 \ldots \ldots . . \mathrm{X} 8$.
The formation of the logistic model was based on the hypothesis that a farmer's decision to adopt or reject new technologies at any time is influenced by the combined effect (simultaneous) effect of hypothesized socioeconomic factors. The variables that were used in the logistic model were estimated using the maximum likelihood method.

Where $Y_{i}=$ use of $i^{\text {th }}$ soil management practice (use $=1,0$ otherwise)

$\mathrm{X}_{1}=$ Total farm size (ha)

$\mathrm{X}_{2}=$ Age of farmer (years)

$\mathrm{X}_{3}=$ Education level

$X_{4}=$ Number of visits by extension agents

in the year.

$$
\begin{aligned}
\mathrm{X}_{5} & =\text { Number of farm plots } \\
\mathrm{X}_{6} & =\text { Total labour used (Mandays) } \\
\mathrm{X}_{7} & =\text { Household size } \\
\mathrm{e} & =\text { Error term }
\end{aligned}
$$

\section{RESULTS AND DISCUSSIONS Demographic and Socioeconomic characteristics of respondents}

The result shows that the modal age group of respondent is 40-59years. The mean age of the farmers is 44 years with about $93.2 \%$ of the respondents are within the active age range of 2059 years. This implies that most of the farmers are strong and energetic and they were still in their economic active age that can make positive contribution to agricultural production. Most (95.8\%) of the respondents are male which implies that cereal farming in the study area is largely male dominated. About $92.4 \%$ of the respondents are married. This implies that high proportion of farmers who are married is an indication that family labour could be available for production. The study shows that only $19 \%$ of the respondents have no formal education. This implies that the farmers likely have some form of knowledge of soil management practices. About $94 \%$ of the farmers had household sizes of between 2 to 15 members with an average of 9 members. This likely means the respondents have adequate family labour for farm operations especially to make use of soil management practices which are labour intensive. Majority (87.2\%) of the respondents have farm size between 0.4 and 3.0hectares with an average of 2.2 hectares. The modal farm size is 1-2 hectares. This implies that the respondents had small holdings are small scale farmers. For $40.7 \%$ of the respondents, farming is a minor source of income meaning they are involved in both agricultural and non-agricultural business and other jobs. About $91.5 \%$ of the farmers had been in farming for over 10 years with an average 
Identification of Common Soil management Practices among Cereal farmers Table 1: Descriptive Statistics Result of the different Soil Management Practices Available

\begin{tabular}{lccc}
\hline $\begin{array}{l}\text { Soil Management } \\
\text { Practices }\end{array}$ & $\begin{array}{c}\text { Number of } \\
\text { Farmers (Adopters) }\end{array}$ & $\begin{array}{c}\text { Distribution } \\
(\%)\end{array}$ & $\begin{array}{c}\text { Number of } \\
\text { Farmers (non- } \\
\text { Adopters) }\end{array}$ \\
\hline Crop Rotation & 88 & 74.6 & 30 \\
Green Manuring & 1 & 0.8 & 117 \\
Plant Residue management & 11 & 9.3 & 107 \\
Use of fertilizer & 82 & 69.5 & 36 \\
Manure & 11 & 9.3 & 107 \\
Use of Cover Crop & 48 & 40.7 & 70 \\
Bush fallow & 23 & 19.5 & 95 \\
Ridging & 111 & 94.1 & 7 \\
Zero tillage & 31 & 26.3 & 87 \\
\hline Source: Field Survey 2012 & & &
\end{tabular}

\section{Regression Analysis}

Table 2: Maximum Likelihood Estimate of Logistic Regression Analysis of Socioeconomic factors affecting the use of Soil Management Practices

\begin{tabular}{|c|c|c|c|c|c|c|}
\hline \multirow[b]{2}{*}{ Variables } & \multicolumn{5}{|c|}{ Soil management practices } & \multirow[b]{2}{*}{ Ridging } \\
\hline & Crop rotation & $\begin{array}{l}\text { Cover } \\
\text { Cropping }\end{array}$ & $\begin{array}{l}\text { Bush } \\
\text { Fallow }\end{array}$ & Zero Tillage & $\begin{array}{l}\text { Use of } \\
\text { Fertilizer }\end{array}$ & \\
\hline Farm size $\left(\mathrm{X}_{1}\right)$ & $-0.499 * * *$ & 0.125 & -0.011 & $0.817 *$ & 0.049 & -0.367 \\
\hline Age $\left(X_{2}\right)$ & $0.085 * * *$ & -0.015 & -0.001 & $0.101 * *$ & -0.007 & 0.059 \\
\hline Education $\left(\mathrm{X}_{3}\right)$ & 0.104 & 0.024 & 0.001 & 0.096 & $0.100 * *$ & 0.069 \\
\hline Contacts with Extension agents $\left(\mathrm{X}_{4}\right)$ & $-0.605^{*}$ & $-0.294 *$ & $-0.363 *$ & $0.576^{*}$ & $0.319 * *$ & -0.096 \\
\hline Number of Farm Plots $\left(\mathrm{X}_{5}\right)$ & $-2.575 *$ & $-1.286 * *$ & -0.676 & $2.622 *$ & -0.480 & -0.341 \\
\hline Labour $\left(\mathrm{X}_{6}\right)$ & 0.005 & 0.0001 & 0.002 & -0.005 & $0.006 * *$ & 0.002 \\
\hline Household size $\left(\mathrm{X}_{7}\right)$ & $-0.179 * * *$ & -0.087 & -0.010 & $0.200 * * *$ & 0.068 & -0.198 \\
\hline Constant & 4.697 & 2.998 & -0.166 & -4.997 & -1.498 & 2.931 \\
\hline $\mathrm{R}^{\wedge^{2}}$ & 0.526 & 0.279 & 0.163 & 0.548 & 0.386 & 0.107 \\
\hline
\end{tabular}

Source: Data Analysis, 2012.

farming experience of 25.6 years. 20years was the most common within the study area. This indicates that the farmers are highly experienced in cereal farming. A large number $(45.8 \%)$ of the farmers have no contact with extension agents within the last planting season this may be due to their abstinence from meetings held by the extension agents for the farmers which was affirmed by the farmers. This could affect their level of awareness of about some soil management practices. Although on the average, the farmers had visits at least twice in a year. $50 \%$ of the respondents depended on local knowledge and information from family and friends for their soil management practices. This implies that the respondents still depended on their local knowledge and may not make use of soil management practices that may likely boost their production

The analysis shows that ridging is the most prevalent type of soil management practice with about $94 \%$ of the respondents practicing it. Although it is usually seen as part of land preparation method but it also doubles as a type of soil management practice in that it helps to conserve water in the soil and also serve as erosion control measure. Also it is a traditional practice. About 74.6 percent of the farmers practice crop rotation and $69.5 \%$ of the respondents used fertilizer. This implies that crop rotation is a common practice among the farmers in the study area. The practice also comes as the second most common practice after ridging. This may be due to farmers finding an alternative for the use of fertilizer where it is scarce and costly. Green manuring $(0.8 \%)$ is not a common practice in the study area. The farmers complained of its scarcity, bulkiness and high cost of application. $26.3 \%$ of the respondents practiced zero tillage; zero tillage was most prevalent among the rice farmers in the study area. This was usually done when there is no availability of tractors at the time of land preparation for the planting of seeds. So in order to save time and plant at the right time, they resort to the use of zero tillage. Bush fallow is also an uncommon practice among the farmers with $19.5 \%$ of the farmers currently practicing it. This may be due to greater dependency of the respondents on the use of fertilizer. The range of the fallow is between 1 to 5 years in most parts of the study area. The land is usually left to regenerate on its own. Only $9.3 \%$ of the respondents practice plant residue management. Some of the farmers leave plant residue in the furrows to rot and add nutrient to the soil after their initial land clearing 
operation or they are ploughed back into the soil by those who can employ tractor services. $*$ Significant at $1 \%$;** Significant at 5\%;*** Significant at $10 \%$

The result shows that $54.8 \%, 52.6 \%, 38.6 \%$, $27.9 \%, 16.3 \%$ and $10.7 \%$ of variation in the use of zero tillage, crop rotation, use of fertilizer, cover cropping, bush fallow and ridging were explained by the independent variables given their pseudo R-square values. Positive values of coefficient implies that increasing independent variables would increase the farmers likelihood to use soil management practices, while those with negative values of coefficient would decrease the farmers likelihood to use soil management practices.

Farm size positively influenced the use of zero tillage at $1 \%$ level of significance implying that those with large farm size has probability of making use of zero tillage. While farm size negatively influenced the use of crop rotation at $10 \%$ level of significance which implies that as farm size decreases the farmers may likely increase the use of crop rotation. The age of the household head was positive and significant at $10 \%$ probability level for the use of crop rotation, while the situation was different for the use of zero tillage which was negatively influenced by age of the household head at 5\% probability level. This may be as a result that younger farmers are more innovative and better adopters than older farmers as well as the fact that such practice will reduce their stress and cost of cultivation.

The educational level of the farmers positively influenced the use of fertilizer by the farmers which is significant at $5 \%$. The higher the educational status of the farmers, the higher their likelihood to use fertilizer. The coefficient of number of contacts with extension agents is negative for crop rotation, cover cropping and bush fallow except zero tillage and the use of fertilizer which had a positive coefficient. This result shows that the use of zero tillage practice and use of fertilizer will likely increase as the number of contacts with extension agents increases. On the other hand, as the farmers contact with extension workers reduces the farmers probability of using crop rotation, cover cropping, bush fallow will likely increase. This is in line with earlier findings (see Table 2) that about $45 \%$ of the respondents had no contact with the extension agents. This implies that the farmers will likely rely more on their local knowledge and practices they are used to (traditional practices).

The number of farm plots cultivated to cereals positively influenced the use of zero tillage at $1 \%$ probability level implying that farmers will likely use more of zero tillage practice as their farm plots increase in number. While crop rotation and cover cropping practices were negatively influenced by the number of farm plots at $1 \%$ and $5 \%$ levels of probability, respectively. This indicates that as the number of farm plots cultivated to cereals by the farmers' increases they will likely use less of crop rotation and cover cropping practices. According to Aromolaran (1998) findings in a similar study, he observed that the major problem with cover cropping practice is the opportunity cost which the farmers consider to be very high. This could likely be the reason for the reduced likelihood of farmers in this study area to use crop rotation and cover cropping as there farm plots increases. Labour used positively influenced the use of fertilizer at the $5 \%$ probability level, an implication that labour availability increases the farmers' probability to use fertilizer.

\section{CONCLUSIONS AND RECOMMENDATIONS}

The study reveals that the farmers have some form of knowledge about soil management practices. Visits from extension workers also influence the use of some of the soil management practices. There have been low contacts between the farmers and the extension workers and this reduces the rate of information passed across to farmers and also affects the adoption of these practices among the farmers. Soil degradation in cereal fields can be reversed, but it requires long term commitments and usage of better soil management practices which will also improve the productivity of the farmers. Therefore it is recommended that Green manuring, zero tillage, plant residue management and the use of manure should be encouraged among the farmers because of their proven efficacy in improving the soil. The frequency of visits by extension workers should be increased and extended to all farmers and as well, they should include practical exposure of farmers to the benefits of practicing soil management which will likewise enhance their efficiency level. This will help boost their productivity as well bring about soil improvement. Farmers too should be encouraged to attend meetings, on-farm demonstrations, trainings and workshops organised by the extension workers for farmers as this will encourage a wider adoption of soil management practices

\section{REFERENCES}

Aromolaran, A.B. (1998) "Economic Analysis of Soil Conservation Practices in South western Nigeria" In issues in African Rural Development. Monograph Series; Monograph \#11 African Rural Sciences Research Networks.

Aruleba, J.O. (2004) Influence of Cropping System, Land Type and Suitability on Land Degradation in South western Nigeria. An 
unpublished Ph.D. Thesis of University of Ibadan. Pp 244.

Aruleba, J.O.and Ajayi, A.S. (2011) "Use of Models in Assessing the Impact of Cropping System, Land Type and Suitability on Land Degradation in South western Nigeria" African Journal of Agriculture Research, 6(5):1090 - 1096.

Bationo, A., Traore, Z., Kimetu, J., Bagayoko, M., Kihara, J., Bado, V., Lompo, M., Tabo, R. and Koala, S. (2004) "Cropping Systems in the Sudano-Sahelian Zone: Implications on Soil fertility Management".Accessed from www.syngentafoundation.org/db/1/432.pdf on 13th July, 2011.

Cassman, K.G. (1999) "Ecological Intensification of Cereal Production Systems: Yield Potential, Soil Quality and Precision Agriculture". Proceedings of the National Academy of Sciences of the United States Proceedings of America. 96(11): 5952-5959.

Census (2006). National population Census.

Ismaila, U., Gana, A.S., Tswanya, N.M. and Dogara, D. (2010) "Cereals Production in Nigeria: Problems, Constraints and Opportunities for Betterment" African Journal of Agricultural Research, 5 (12): 1341-1350.

Junge, B., Deji, O., Abaidoo, R., Chikoye, D. and Stahr,k. (2007) "Assessment of Past and Present Soil Conservation Initiatives in Nigeria". Conferenceon International Agricultural Research for Development. University of Kassel-Witzenhausen and University of Gottingen, October 9-11, 2007.

Kano Soil Health Project (2010) "Improving Productivity of Smallholder Milletand Sorghum Based Production Systems in the Semi-arid Region ofNorthern Nigeria through Increased Use of Integrated Soil Fertility Management Options and Better Access to Markets". A Project Justification. Retrieved from www.kanosoilhealthproject.net on $12^{\text {th }}$ June, 2011.

KWADP (2008) Crop Area Yield Survey, Kwara State agricultural Developmnet Project, Ilorin, Nigeria. Kwara State Ministry of Information (2002) "Kwara State Dairy 2002". 1-10.
Mrabet, R. (2011) "Effects of Residue Management and Cropping Systems on wheat Yield Stability in a Semiarid Mediterranean Clay Soil". American Journal of Plant Sciences 2: 202-216.

Muhamman, M.A. and Gungula, D.T. (2006) "Cover Crops in Cereals Based Cropping Systems of Northern Nigeria: Implication on Sustainable Production and Weed Management". Journal of Sustainable Development in Agriculture and Environment 2(1):151-162.

Oluwatosin, G.A., Adeyolanu, O.D., Idowu, O.J. and Adediran, J.A. (2005) "Planning Sustainable Soil Management under Intensified Crop Production System in Nigeria: An Ecosystem Approach" Global Journal of Agricultural Sciences, 4(1): 45-54.

Porpavai, S., Devasenapathy, p., Siddeswaran, K. and Jayaraj, T. (2011) "Impact of Various Rice Based Cropping Systems on Soil Fertility" Journal of Cereals and Oilseeds, 2(2): 43-46.

Rahji, M.A.Y., and Omotesho, O.A. (2006) "Technical Inefficiency and Competitiveness in Production: the Case of Rice Farmers in Niger State, Nigeria". Agrosearch 8 (1\&2): 67-79.

Tarawali, G. (1998) "A Synthesis of the Crop-livestock Production Systems of the Dry Savannas of West and Central Africa". IITA-Ibadan.

Tekwa, I.J., Olawoye, H.U. and Yakubu, H. (2010) "Comparative Effects of Separate Incorporation of Cow Dung and Rice Husk Materials on Nutrient Status of some Lithosols in Mubi, North East Nigeria". International Journal of Agriculture and Biology 12: 857-860.

Tekwa, I.J. and Belel, M.D. (2008) "Effectiveness of some Localized Soil and WaterConservation Techniques on sustainable Crop Production in Mubi, Adamawa State". A Paper Presented at the $32^{\text {nd }}$ National Conference of the Soil Science Society of Nigeria (SSSN). Yola, Nigeria: 138-146.

Wikipedia: Soil Management Practices 